\title{
Tomates y otras Verduras de Semilla: Practicas Seguras para Consumidores ${ }^{1}$
}

Amy Simonne ${ }^{2}$

Una variedad de frutas y vegetales deben de ser parte de una dieta sana y saludable. Los tomates y otras verduras de semilla nos brinda nutrientes importantes para nuestra salud. Estos también pueden causar intoxicación alimenticia si no es manejado apropiadamente. Aquí están los pasos que usted puede seguir para reducir el riesgo de intoxicación alimenticia que son causados por tomates u otras verduras de semilla.

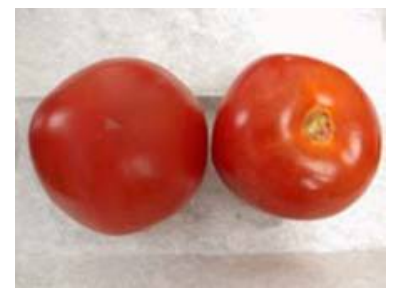

\section{Donde Usted Hace Sus Compras}

- Compre tomates u otras verduras con semilla como el pimiento, que no este dañadas o mallugadas.

- Mantenga los tomates y verduras con semilla separado de la carne crudas, carne de ave y pescado.

- El corte fresco de tomates y verduras con semilla deben de permanecer refrigeradas..

\section{En la Casa}

- Los tomates enteros y el pimiento maduro no necesitan estar refrigeradas. Estas desarrollan menos sabor si están guardados al frió. Otros vegetales como el pimiento verde y el pepino deben permanecer refrigerados.
- Todo el producto fresco debe de permanecer refrigerado dentro de dos horas de haber sido pelado o cortado.

- Deseche las sobras del corte de tomate después de dos horas a temperatura ambiente.

\section{Durante Preparación:}

- Lavarse las manos con jabón y agua tibia después y antes de:

- El manejo del producto fresco

- El manejo de carne cruda, aves caseras o mariscos fresco

- Usar el baño

- Cambiar pañales

- El manejo de animales

1. Este documento, FCS8738-Span, es uno de una serie del Departamento de Ciencias de la Familia, Juventud y Comunidad, del Servicio de Extensión Cooperativa de Florida, Instituto de Alimentos y Ciencias Agrícolas, Universidad de Florida. Fecha de publicación: Noviembre 2002. Revisado: Marzo 2006. Traducido Junio 2007 al español por Marcela Lacayo y Samara Vasquez. Favor de visitar el EDIS en el http://edis.ifas.ufl.edu

2. $\quad$ Amy Simonne, Ph.D., Profesora Asociada, Departamento de Ciencias de la Familia, Juventud y Comunidad, Instituto de Alimentos y Ciencias Agrícola, Universidad de Florida, 32611.

El Instituto de Alimentos y Ciencias Agrícolas es un empleador que provee Oportunidades Igualitarias, autorizado a proveer investigación, información educativa y otros servicios, únicamente a los individuos e instituciones que operan sin discriminación alguna con relación al credo, color, religión, edad, incapacidad, sexo, orientación sexual, estado civil, nacionalidad, opinion política o afiliaciones. Para más información sobre como obtener otras publicaciones de extensión, comuníquese con la oficina de Servicio de Extensión de su condado. Servicio de Extensión de la Florida / Instituto de Alimentos y Ciencias Agrícolas / Universidad de la Florida / Larry Arrington, Decano. 
- Enjuague el tomate u otras verduras de semilla con agua fría antes de comer o preparar. No use jabón o detergentes.

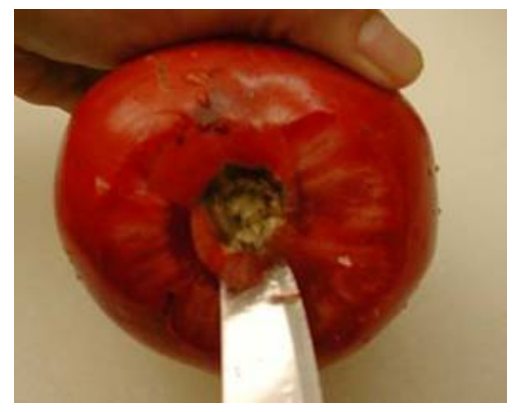

- Ciertos tipos de tomates después de haber sido cosechados son colocados en un tanque de descarga que contiene desinfectante. La bacteria que sobrevive de este procedimiento usualmente se encuentra cerca del tallo. Siempre remueva el tallo del tomate con un cuchillo limpio antes de cortar o picar para ser consumido crudo.

- No consuma las verduras de semilla como el pimiento que tienen hoyos. Estos pueden estar contaminados.

- Deseche los vegetales que tengan hoyos o estén dañados o mallugados. Los microbios se pueden esconder o invadir fácilmente el resto de la fruta por las áreas que están dañadas.

- Lave tabla de cortar, platos, utensilios y la cima a menudo. Utilice agua tibia con jabón y enjuague bien. Desinféctelos después de ser usado con algún producto fresco, carne cruda, aves caseras o mariscos (mire la casilla).

- Desinfecte el área de lavaplatos con frecuencia para reducir la acumulación de microbios.

- ¡No cruce contamine! Utilice la tabla de cortar e utensilios que estén limpios para el producto fresco.

- $\quad$ Si puede, utilice diferentes tablas de cortar para carne cruda, aves caseras o mariscos.
- No consuma el hielo que ha estado en contacto con el producto fresco u otros productos crudos.

- Utilice una hielera con hielo cuando usted toma alimento perecedero fuera. Esto incluye vegetales y corte de frutas frescas.

\section{Para desinfectar tabla de cortar, platos y utensilios:}

Mezcle una cucharada de cloro en un cuarto de agua.

Vierta la mezcla en la superficie o sumerja los artículos en la solución y déjelo allí dentro por lo menos un minuto.

Enjuague con agua caliente.

Las cimas pueden ser desinfectadas usando la solución anterior. Spray desinfectantes y toallitas de limpiar funcionan como medida adicional de seguridad.

Siguiendo estos pasos reduce el riesgo de la intoxicación alimenticia que son causados por productos frescos.

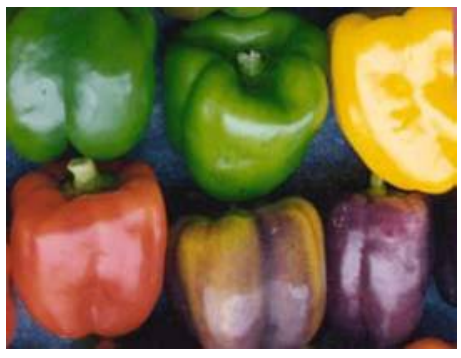

\section{Para Más Información:}

Visite la página Web de Food and Drug Administration (FDA): http://www.fda.gov o llame FDA Indagaciones de Consumo al 1-888SAFEFOOD (número de llamada gratuita). 